\title{
ANALYSIS OF BUSINESS MODELS FOR THE TAKAFUL FUND MANAGEMENT
}

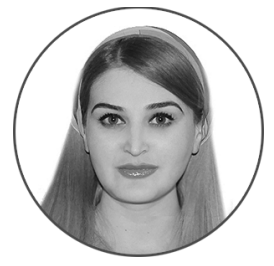

Article history:

Received 10 May 2018

Received in revised form

24 May 2018

Accepted 7 June 2018

Translated 10 July 2018

Available online 28 September 2018

JEL classification: G22

Keywords: Takaful, mechanism, Wakalah, Mudharabah, management

\author{
Madina M. MAGOMADOVA \\ Chechen State University (ChStUn), Grozny, Chechen Republic, Russian Federation \\ madina.magomadova@mail.ru \\ https://orcid.org/0000-0002-8049-2054
}

\begin{abstract}
Importance Whereas Takaful implies mutual guarantees, it does not contravene fundamental principles of Federal Law of November 29, 2007 № 286-Ф3 On Mutual Insurance as non-profit mutual insurance. The Takaful fund management mechanism does not dramatically diverge from the conventional European or American insurance. However, the implementation models differ significantly, laying the basis for this research.

Objectives The research substantiates Takaful fund management models in accordance with the effective Russian laws on insurance, and infers a more adequate model.

Methods The research involves analysis, synthesis, systematization, classification, generalization, comparative analysis of structure and systems approach.

Results I perform a comparative analysis of the existing business models for Takaful fund management. The article substantiates such models in terms of the effective Russian laws on insurance and introduces an adequate business model which would unfold the potential of Takaful in the insurance system of Russia.

Conclusions and Relevance If business models for Takaful fund management are implemented in accordance with the existing laws on insurance, this will lure the Muslim population into the insurance sector. Their participation in financial operations will contribute to the development of Islamic finance and overall financial market of Russia.
\end{abstract}

๑) Publishing house FINANCE and CREDIT, 2018

The editor-in-charge of this article was Irina M. Vechkanova

Authorized translation by Irina M. Vechkanova

Although regulatory documents point out two segments of insurance - property and personal, various scholars crystallize three, four or even five ones. For example, V.G. Larionov, M.N. Skrypnikova [1] indicate insurance of person, property, liability and business risks. The same views are expressed by Yu.T. Akhvlediani [2], N.A. Chigasova [3], L.M. Sadykova, E.V. Korobeinikova [4]. Some authors (R.S. Rodin [5], I.P. Khominich [6], M.A. Fedotova ${ }^{\text {, }}$ I.M. Shor [7], E.G. Knyazeva [8]) discuss only three

\footnotetext{
${ }^{\dagger}$ For the source article, please refer to: Магомадова М.М. Анализ бизнес-моделей управления такафул-фондом. Финансы и кредит. 2018. T. 24. № 6. C. 1366-1384.

URL: https://doi.org/10.24891/fc.24.6.1366

${ }^{1}$ Fedotova M.A. [Insurance company's risks]. Finansy $i$ kredit $=$ Finance and Credit, 2009, no. 42, pp. 66-72.

URL: https://cyberleninka.ru/article/v/riski-strahovoy-kompanii (In Russ.)
}

segments, such as insurance of property, person and liability. It is worth mentioning that the Russian laws (Chapter 48 of the Civil Law of the Russian Federation and Law of the Russian Federation of November 27, 1992 № 4015-1 On the Insurance Business Process in the Russian Federation) set forth two segments of insurance, i.e. personal and property one. Property insurance, indeed, includes three segments, such as insurance of possessions, civil liability and business risks, being generally compliant with Article 6 of Sharia Standard No. 26, which envisages insurance of property (general Takaful) and person (family Takaful).

1. Property insurance (known as the general Takaful in some countries and Russia) defrays actually incurred 
costs in case of genuine damage and provides coverage in case of fire, road accidents, aviation accidents, incidence of liability, attorney-in-fact's breaches, etc.

The general Takaful provides for short-term contracts. It rests upon the idea of indemnification, reimbursement of losses through mutual assistance. Therefore, the general Takaful is to protect from tangible losses or damage to the Takaful contributors' property, using the common Takaful fund made up of contributions.

The pool of Takaful funds for insurance benefits may be scarce. Such situations are common during the first years of the Takaful company's operations. The Takaful operator grants an interest-free loan to the Takaful holders, or Takaful holders regain the balance of the Takaful fund by making additional contributions.

As part of the profit-making model of the general Takaful, return on investment is distributed among Takaful holders and Takaful operation on principles of the Mudharabah contract. As per Article 12 of Shariah Standard No. 26, the Sharia Supervisory Board for Takaful approve the terms on which policyholder surplus is allocated.

What matters in the general Takaful and resembles the conventional property insurance is that the Takaful operator monitors the insured item. That is, Takaful operators evaluate the item insured on a regular basis. The reason is that the item insured can get impaired during the Takaful contract period because it causes the uncertainty and usury, giving profiteering opportunities for one party with respect to the other one.

The Takaful operator's profit depends on a type of the Takaful fund management model it adopts.

Hence the following structure is typical of the general Takaful (property insurance) (Fig. 1).

In the general Takaful practice, the term of an insurance contract usually equals one year. When an insurance policy expires, it is prolonged and renewed. Some Muslim scholars underline the nexus of the Takaful contract and various financial institutions of the Sharia community.
2. Family Takaful, or personal insurance, applies to risks of disability or death against the life insurance accepted in the conventional insurance system.

Disability or death risks are insured if the following conditions are met:

- an application is filed for joining the plan, indicating all personal details and characteristics which shall be available to provide insurance coverage. There shall also be detailed information about expected payouts and the Takaful holder's liabilities;

- the contribution amount shall be indicated;

- reimbursement amounts shall be specified as due to the beneficiary in accordance with the contract.

There are three principal models of Takaful companies and conclusion of contracts used in their operations, mutual, commercial and agency. The mutual model is sometimes called cooperative by some scholars (for example, S.P. Fukin [9], A.S. Sholoiko [10]) but it turns to be incorrect in terms of the Russian laws on insurance. I review their distinctions in paragraphs below.

The Muslim legal experts initially intended to forge the Takaful practice as a mutual model relying upon the idea of brotherhood and mutual help, thus echoing the ideal of conventional mutual insurance. As per the elementary mutual model, Takaful funds are not invested but rather used to make payouts to contributors upon an insurable event. However, the mutual insurance principle, as is construed in Federal Law of November 29, 2007 № 286-Ф3 On Mutual Insurance, is observed in case when the Takaful funds are invested through an agency (Wakalah) contract and subsequent return on investment is earmarked to increase the Takaful funds. The mutual insurance model was pioneered in Saudi Arabia and Sudan as the basic one. However, insurers searched for profit-making opportunities, thus fostering commercial business models of Takaful, which were discovered in Malaysia. As set forth in Article 21 (paragraph 21.7) of Act 312 (Takaful Act 1984, Malaysia), the pool of Takaful funds, which are not earmarked for administrative and other expenditures, can be invested in accordance with the Minister's instructions provided they comply with the Sharia

Please cite this article as: Magomadova M.M. Analysis of Business Models for the Takaful Fund Management. Digest Finance, 2018, vol. 23, iss. 3, pp. 308-318. 
principles. The return on investment will be remitted to the Takaful guarantee scheme.

As Kh.S. Umarov puts it [11], the basic commercial model is based on an ordinary contract of the so called pure Mudharabah for the Takaful fund investment (Fig. 2).

Pure Mudharabah is mainly suitable for personal insurance purposes (family Takaful), rather than for property insurance (general Takaful). The Takaful operator handles funds of contributors, who are entitled to get the entire policyholder surplus (profit from insurance). The return on investment of Takaful funds is shared among the contributors and Takaful operator in line with their agreed shares. Before the return on investment is shared, deductions are not allowed. All costs the Takaful company incurs are defrayed with its share in profit.

In the future, hybrid Mudharabah came into practice (the general Takaful) (Fig. 3).

What distinguishes the mutual Takaful model from the commercial one is that the mutual model requires to share policyholder surplus among contributors and Takaful operators, rather than profit, as much as stipulated in the insurance contract. Surplus arises when the total contributions for the financial period and reinsurance premiums exceed total insurance payouts for the same period and after costs and changes in technical reserves are deducted as corroborated in the research referred to hereinafter $[12,13]$.

It is incorrect to say that the commercial model is based on the Mudharabah contract only. As mentioned above, Shariah Standard No. 26 stipulates investments through the Wakalah agency contract without a Takaful operator having interest in ROI. The commercial and agency-based models and their substance coincide, borrowing certain components from one another.

As per the general rule of the agency-based model, relationships between contributors and Takaful operator are governed by an agency contract (Wakalah). The Takaful operator derives its agency fees for the Takaful fund management from a part of contributions. Under the agency model the Takaful operator receives a flat amount (fee) from contributors, which the Takaful operator uses to cover its expenditures. The agency-based model assigns all risks to the Takaful holders. For example, if the amount of insurance benefits exceed the amount of insurance premiums, which contributors donate, the latter shall cover the difference by making additional contributions (Fig. 4).

However, the Takaful operator is not entitled to a surplus since it pertains to contributors, being used in the conventional mutual insurance to decrease insurance premium. The same requirement is set in Article 19 of Federal Law of November 29, 2007 № 286-Ф3 On Mutual Insurance. Like the others, the agency-based model has a hybrid format (Fig. 5).

The kernel of the hybrid agency-based model is that relationships between the Takaful operator and contributors are regulated with the Wakalah contract (agency contract).

Moreover, the Takaful operator acquires the right for a portion of policyholder surplus, which is shared among stakeholders and Takaful operators in a previously agreed proportion after insurance benefits are paid to the insured.

Some international experts in finance recommend to apply the hybrid Wakalah-Mudharabah model, which virtually combines the above models. Under the hybrid model, as a result of its insurance activities the Takaful operator is entitled to a fixed portion of contributions and share in ROI (Fig. 6).

Arabic countries mainly employ the Wakalah agencybased model. In Malaysia the model also involves Mudharabah-based profit. It is noteworthy that the hybrid Wakalah- and Mudharabah-based models proved to be viable and competitive.

Table 1 illustrates the difference between the main models.

Therefore, Mudharabah makes the management of the insurance fund's assets and underwriting the core activity of the Takaful operator. ROI is shared between the Takaful operator and the insured in a preliminarily agreed proportion, while the policyholder surplus (the difference between monetary contributions and insurance benefits in insurable events) is retained within 
the Takaful fund, that is owned by the contributors. To the contrary, in the hybrid Mudharabah model, the policyholder surplus is allocated in a preliminarily agreed proportion among contributors. The Takaful operator's share in ROI is often higher than the immediate share of the Takaful fund. The Wakalah model obliges the Takaful operator act as an agent (Wakil) for the insured (client). In this model, the previously agreed amount of compensation (amount of contributions made by the insured) is put at the disposal of the Takaful operator. In the hybrid Wakalah model like in the hybrid Mudharabah model, policyholder surplus are allocated among contributors and Takaful operator as previously agreed. However, the models are not ultimate from perspectives of the Shariah standards.

Some researchers (I.L. Logvinova [14]) suggest introducing the Waqf construct into the agencybased model (Fig. 7). The insured make their contributions (Tabarru) into the Waqf fund, which is spent to make payouts in case of insurable events.

Shareholders (owners) of the Takaful operator make initial contributions as voluntary donations, thus losing their titles for the funds. However, the title is not conferred on the insured either.

The Waqf model is less common, being applicable in Pakistan, in particular.

Notwithstanding some common traits, the above models diverge when it concerns the fact and method of paying for the Takaful operator's services, and its share in profit:

- share in profit under the Mudharabah model;

- share in profit under the hybrid Mudharabah model;

- agency fees under the Wakalah model;

- agency fees and share in profit under the hybrid Wakalah model;

- share in profit and agency fees under the hybrid Wakalah-Muharabah model;

- share in profit and agency fees under the Waqf model.

The share in profit has the following meaning:
1) ROI under the Mudharabah model;

2) ROI and a portion of policyholder surplus (underwriting income) under the hybrid Mudharabah model;

3) share in profit is not supposed under the Wakalah model;

4) a portion of policyholder surplus under the hybrid Wakalah model;

5) ROI under the Wakalah-Mudharabah model;

6) ROI under the Waqf model. A portion of ROI is generated with contributions the Takaful operator's shareholders make to the Waqf fund.

If we try to compare the Takaful models and types of commercial insurance, the Wakalah model is evident to resemble those ones used in some countries, like Kazakhstan. It is a model that underlies mutual insurance companies' operations. The hybrid Wakalah model can be compared with the model adopted in the conventional commercial insurance.

Despite its conventionality, the Waqf model has a unique distinction in the way the Waqf fund is formed, thus being rather competitive during market research aimed to attract clients.

As for the hybrid models - hybrid Mudharabah and hybrid Wakalah, Takaful holders consider them least lucrative, being very reluctant to let the Takaful operator take some surplus since it hardly ever deserves any credit for the surplus.

As I see it, the Wakalah model and the combination of Wakalah - Mudharabah - Waqf would be reasonable to use in Russia in order to implement the Takaful practice (Fig. 8).

What distinguishes the combined financial business model from the conventional hybrid one is that the Takaful operator acquires legal rights and obligations for donations to the Waqf fund. Waqf arises from the Waqf contract. The pool of the Waqf fund made by contributors can be nominal. The capital serves for conferring the status of right holder on Waqf, rather than for ensuring the solvency of the Takaful company. Shareholders provide funds needed for performance, while the solvency can be supported with the Waqf fund. 
The financial model of Takaful adapts the family Takaful by virtually rearranging business operations of existing life insurers (it is forbidden in Russia, like in many other countries, to combine life insurance and other types of insurance) to comply with the Takaful principles on cost effective terms for insurers. The model will be used if insurers intend to enter a new segment of the Islamic insurance market, on the one hand, and integrate the Islamic finance principles into the effective laws, on the other hand. Pension insurance will reach another development phase in conventional systems and family Takaful if the personal income tax on social security charges remitted to insurance companies for pension benefits is no longer levied when paid by the insured third parties (employers, etc.).

Hence Waqf is supposed to support those who make their contributions to Waqf, become its beneficiaries for the period indicated in donation contracts in the case of losses and financial damages.

The combined financial business model implies distinctive methods for deriving profit - from investment of the Waqf fund and Takaful fund. This makes it very competitive and attractive for clients. The Waqf fund is formed by shareholders, i.e. initial contributions proceed from their donations. Some insurance premiums of shareholders are also added to the Waqf fund as contributions, however shareholders and contributors lose their ownership right for the funds.

The combined financial business model is preferable for the Takaful operator and contributors. The Takaful operator gains agency fees (Wakalah), return on investment of the Takaful fund (Mudharaba), share in profit from the Waqf fund investment management and the Waqf fund management fees (Waqf). In the case of an insurable event contributors is entitles to insurance benefits from the Waqf fund, Takaful fund and return on these funds invested.

The reduction in the insufficient Takaful fund risk is another advantage of the model since insurance benefits will be paid out of two pools of funds, i.e. the Takaful fund and Waqf fund. In the other models, if there is shortage of funds, the Takaful operator grants interest-free loan to the Takaful fund or stakeholders make additional contributions (Tabarru) to cover the difference.

At initial stages of the Takaful company's growth and development, the combined financial business model is preferable since the Takaful company experiences a shortage of funds during the period. The shortage of funds can be offset with the Waqf fund. It takes a certain period of time (two to three years) for the Takaful fund, like any other, to accumulate some surplus and reach the break-even point.

Act 312 (Takaful Act 1984, Malaysia) requires to involve agents and brokers. In such a case the operator appoints an agent at its own discretion. The agent (Wakil) may be employed on a part-time or full-time basis. The agent is supposed to promote insurance products, attract new clients, explain the terms and substance of an insurance policy to the would-be insured before they sign a Takaful contract. Agents act as if they are employees of the company. That is why they take part in sharing the Takaful operator's profit like the other parties to the contract.

Unlike agents (Wakil), brokers shall be duly registered and act as intermediaries on their own behalf as the insurer or insured instructs them to do so. The broker is subject to double liability to parties of the Takaful contract. It serves interests of a contractual party providing them with relevant advice, and those of the Takaful operator promoting its products and attracting new clients. In the Takaful practice the brokerage income is twice as much as the income of an ordinary agent working with the Takaful operator. The broker's income is based on the two systems of Waqf and Mudharabah.

I believe there should be intermediaries in the Takaful scheme since Takaful is rather a new financial institutions that shall be disseminated among the population. Intermediaries may be involved in Takaful deals as part of the combined financial business model proposed herein.

Hence Takaful can be practiced in Russia if the above Takaful fund management models are implemented, thus creating the competition. 


\section{Table 1}

Distinctions of various Takaful models

\begin{tabular}{|c|c|c|c|}
\hline Indicator & Wakalah & Mudharabah & Wakalah-Mudharabah \\
\hline $\begin{array}{l}\text { Takaful operator's } \\
\text { performance }\end{array}$ & $\begin{array}{l}\text { Takaful operator acts as } \\
\text { an agent for the insured. } \\
\text { The Takaful operator } \\
\text { receives a portion of } \\
\text { contributions made by } \\
\text { the insured as previously } \\
\text { agreed and has no interest } \\
\text { in underwriting income or } \\
\text { ROI }\end{array}$ & $\begin{array}{l}\text { Takaful operator acts as an attorney-in- } \\
\text { fact, while contributors are } \\
\text { the principal. The Takaful operator is } \\
\text { responsible for investment } \\
\text { management of the insurance fund's } \\
\text { assets and underwriting }\end{array}$ & $\begin{array}{l}\text { Takaful operator receives a certain portion of } \\
\text { contributions made by the insured, and portion of } \\
\text { ROI. Making their initial donations, owners } \\
\text { (shareholder) of the Takaful operator lose their title } \\
\text { for their contributions. The operator makes an initial } \\
\text { contribution to the fund, assets of which are used in } \\
\text { investing activities. Shareholders are entitled to } \\
\text { specify terms on which their contributions are } \\
\text { utlizied. The insured make their donations for } \\
\text { the fund }\end{array}$ \\
\hline Profit sharing & $\begin{array}{l}\text { Policyholder surplus is } \\
\text { shared among stakeholders } \\
\text { and operators as previously } \\
\text { agreed. Operating } \\
\text { expenses are borne by } \\
\text { the Takaful operator }\end{array}$ & $\begin{array}{l}\text { ROI is allocated as previously agrred. } \\
\text { Policyholder surplus is retained within } \\
\text { the Takaful fund or can be distributed } \\
\text { betwee the Takaful fund and Takaful } \\
\text { operator as previously agreed. } \\
\text { Operating expenses are borne by } \\
\text { the Takaful operator }\end{array}$ & $\begin{array}{l}\text { ROI is allocated as previously agreed. Agency fees are } \\
\text { also taken into consideration. Policyholder surplus } \\
\text { passes into the ownership of the Takaful fund }\end{array}$ \\
\hline
\end{tabular}

Source: Authoring

\section{Figure 1}

The general Takaful model

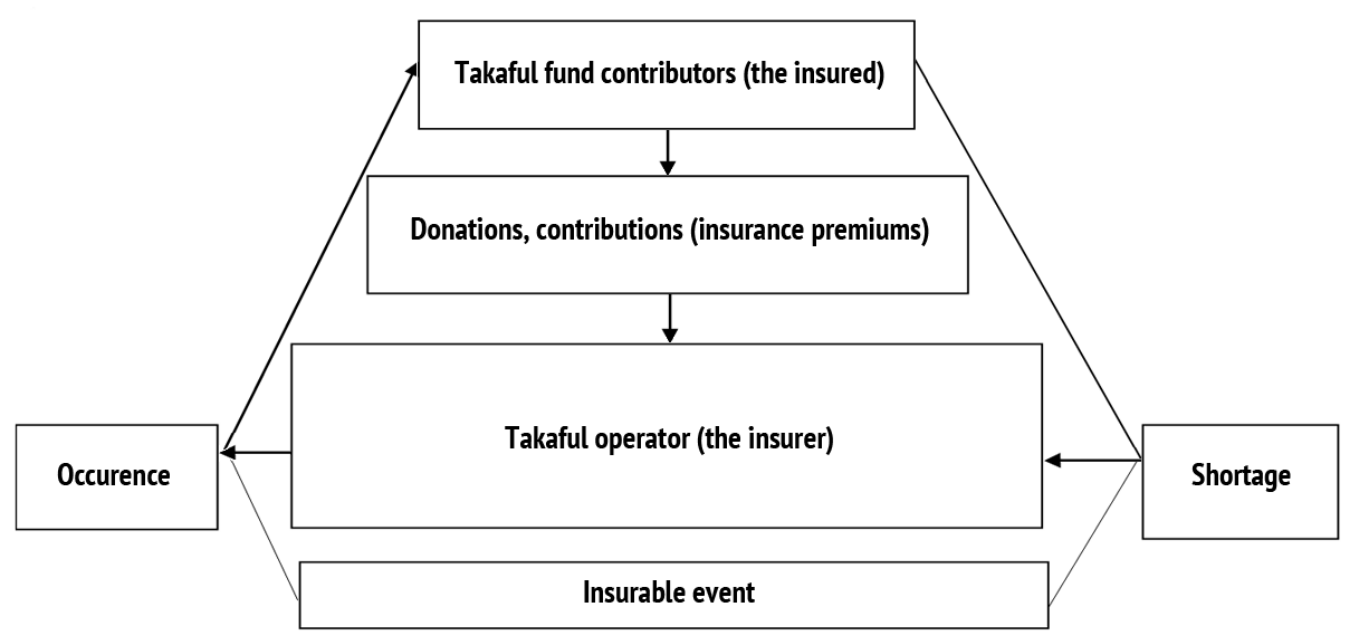

Source:Authoring

Please cite this article as: Magomadova M.M. Analysis of Business Models for the Takaful Fund Management. Digest Finance, 2018, vol. 23, iss. 3, pp. 308-318. 


\section{Figure 2}

The commercial model of Takaful through pure Mudharabah

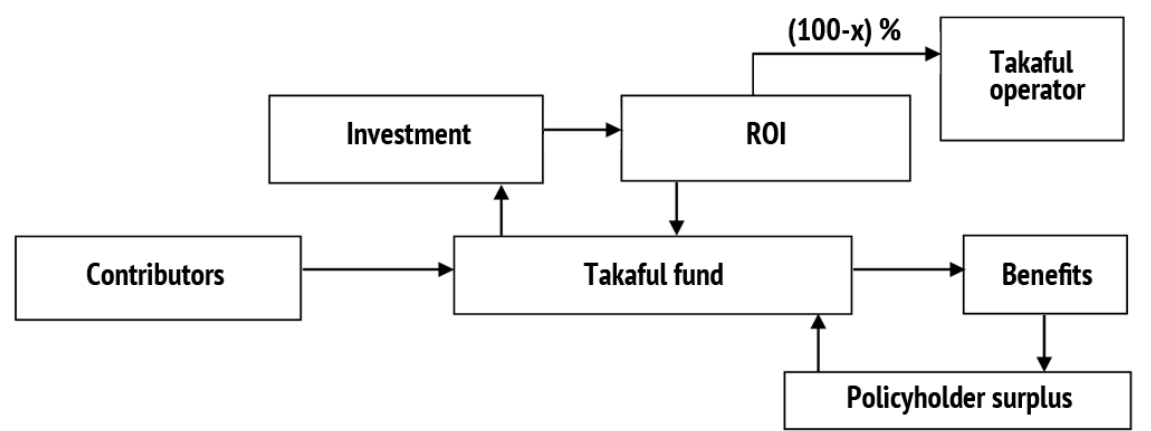

Source: Authoring

\section{Figure 3}

The commercial model of Takaful through hybrid Mudharabah

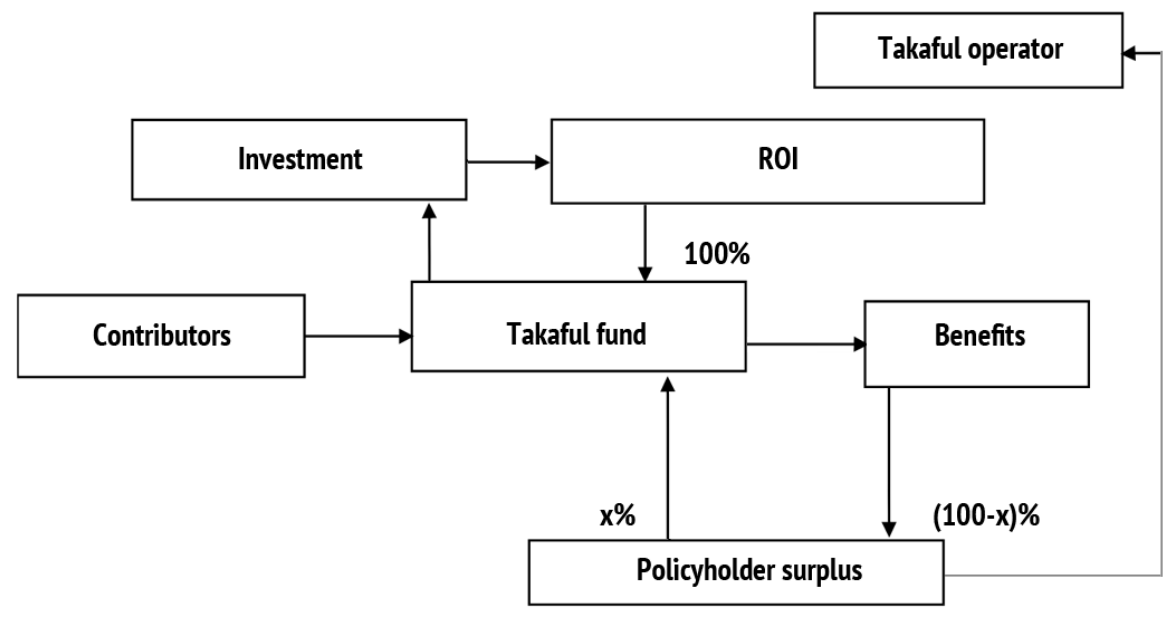

Source:Authoring

Please cite this article as: Magomadova M.M. Analysis of Business Models for the Takaful Fund Management. Digest Finance, 2018, vol. 23, iss. 3, pp. 308-318. 


\section{Figure 4}

The agency-based model of Takaful through Wakalah

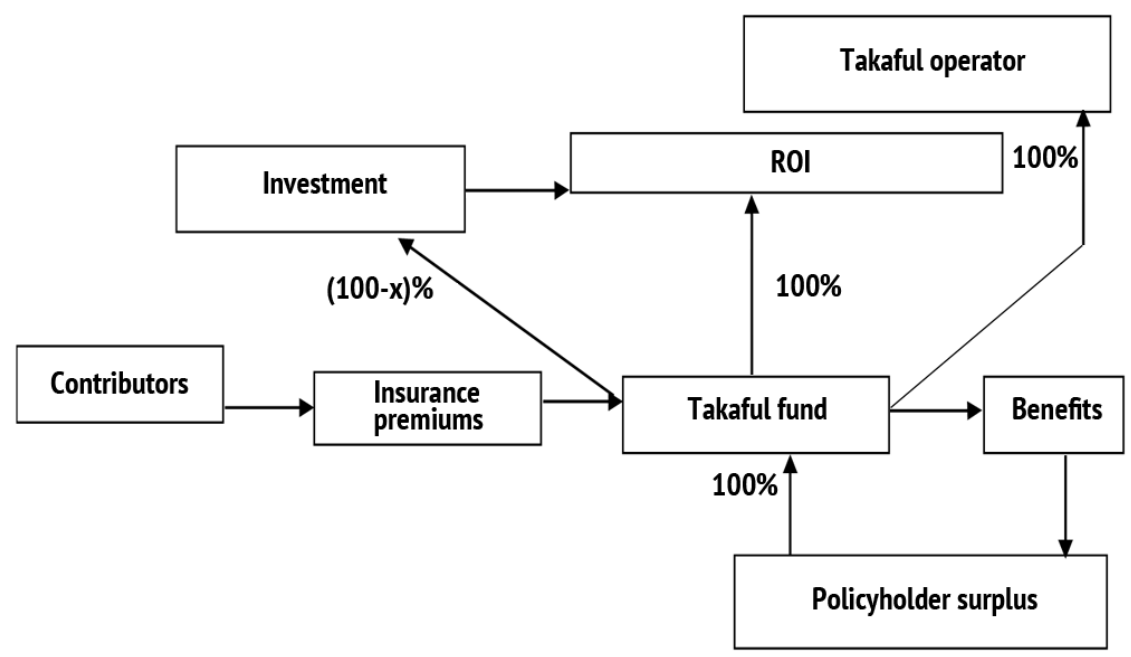

Source:Authoring

\section{Figure 5}

The agency-based model of Takaful through hybrid Wakalah

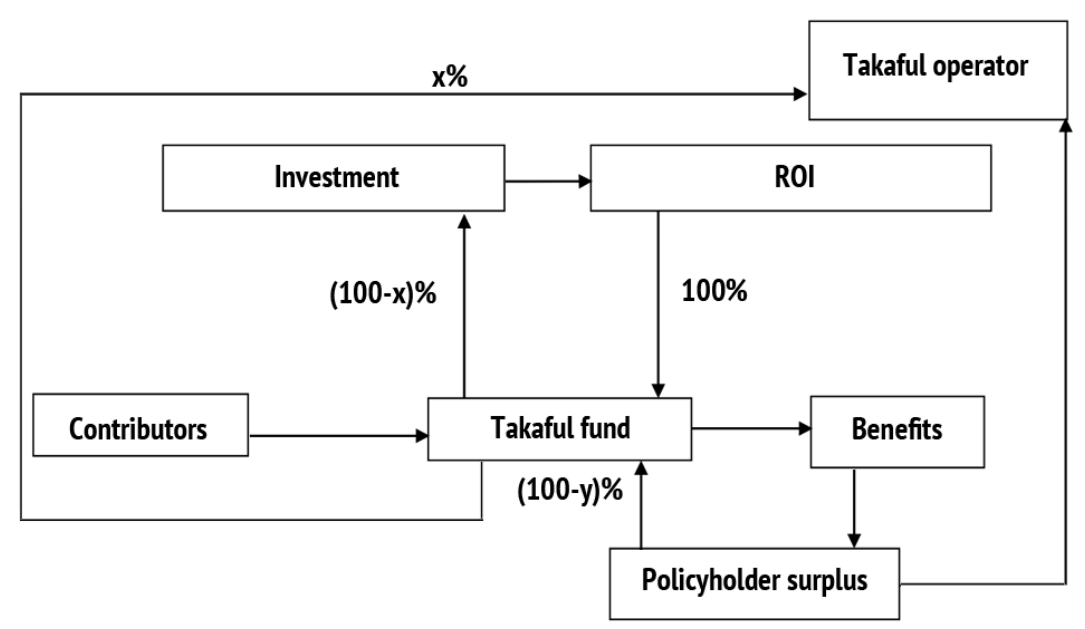

Source:Authoring

Please cite this article as: Magomadova M.M. Analysis of Business Models for the Takaful Fund Management. Digest Finance, 2018, vol. 23, iss. 3, pp. 308-318. 


\section{Figure 6}

The hybrid model through Wakalah and Mudharabah contracts

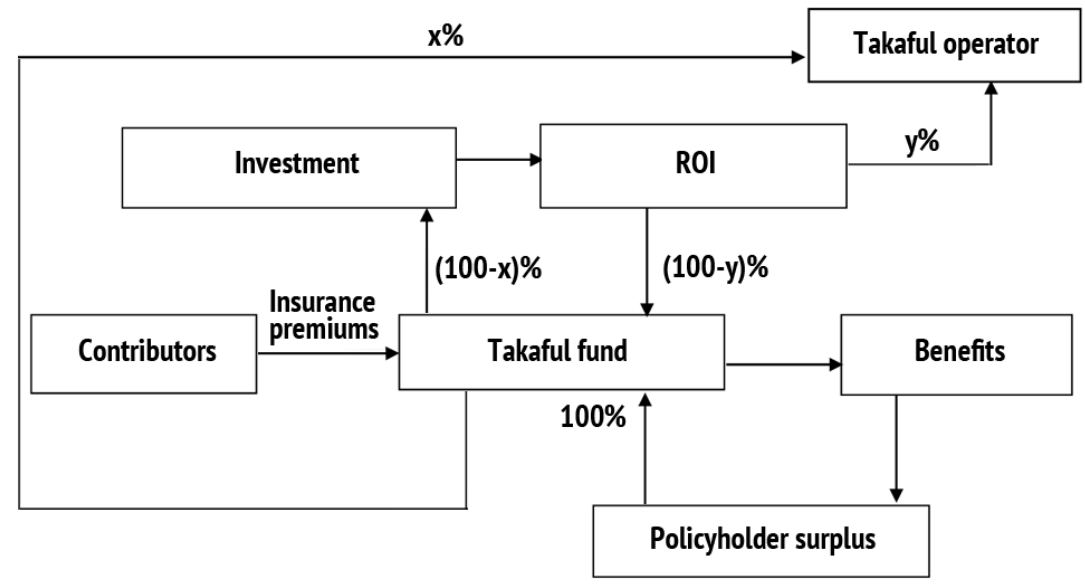

Source:Authoring

Figure 7

The agency-based model through Waqf

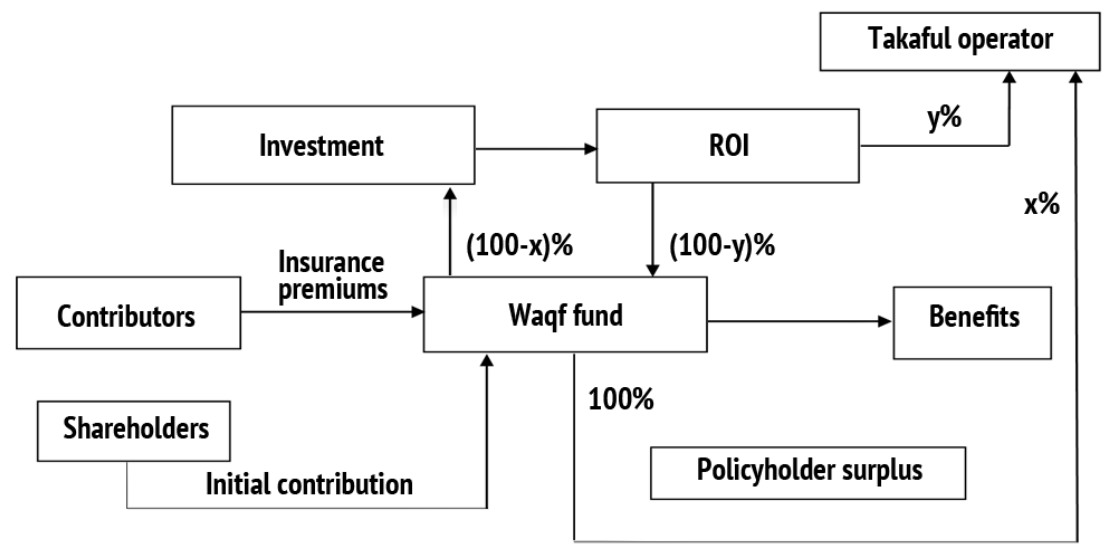

Source:Authoring

Please cite this article as: Magomadova M.M. Analysis of Business Models for the Takaful Fund Management. Digest Finance, 2018, vol. 23, iss. 3, pp. 308-318. 


\section{Figure 8}

The financial model of Takaful through the Wakalah-Mudharabah-Waqf model

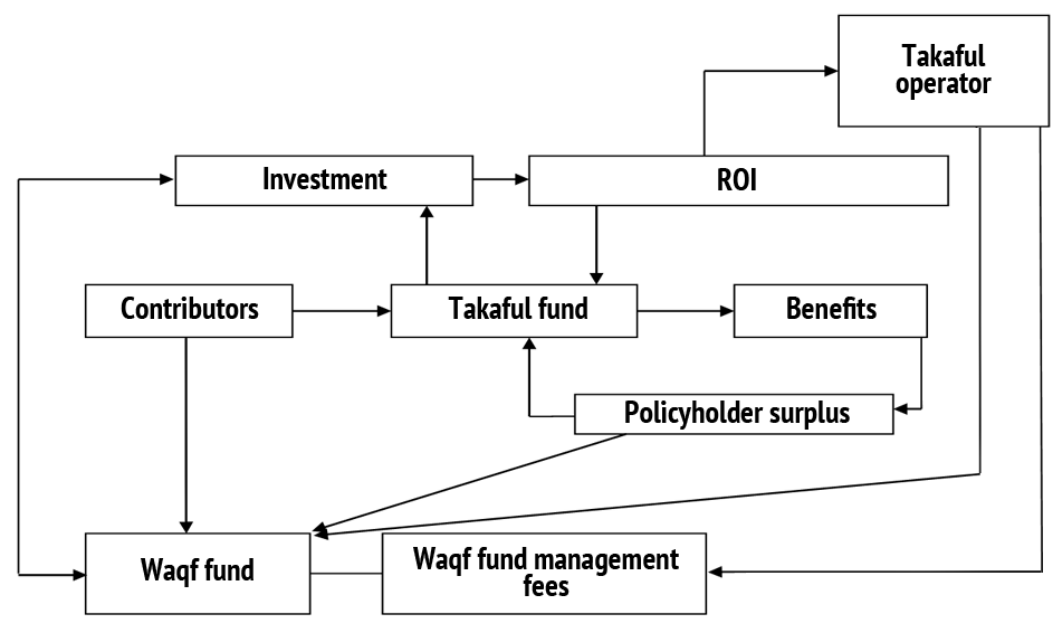

Source: Authoring

\section{References}

1. Larionov V.G., Skrypnikova M.N. [Fundamentals of insurance classification]. Rossiiskoe predprinimatel'stvo = Russian Journal of Entrepreneurship, 2001, no. 1, pp. 49-52. (In Russ.)

2. Akhvlediani Yu.T. [Insurance mechanisms for the protection of consumer rights]. Strakhovoe delo, 2016, no. 11, pp. 31-35. (In Russ.)

3. Chigasova N.A. [Basic principles of insurance classification]. Vestnik TISBI, 2005, no. 2. URL: http://old.tisbi.ru/science/vestnik/2005/issue2/Low7.html (In Russ.)

4. Sadykova L.M., Korobeinikova E.V. [Classification criteria insurance product]. Vestnik Orenburgskogo gosudarstvennogo universiteta = Vestnik of Orenburg State University, 2014, no. 8, pp. 169-174. URL: http://vestnik.osu.ru/2014_8/32.pdf (In Russ.)

5. Rodin R.S. [On the order of conclusion, amendment and termination of the property insurance contract]. Vestnik ekonomicheskoi bezopasnosti, 2016, no. 3, pp. 176-177. URL: http://mosumvd.com/izdatelskayadeyatelnost/periodicheskie-izdaniya/vestnik-ekonomicheskoy-bezopasnosti-mvd-rossii/polnotekstovyenomera-zhurnalov-s-2014-g-full-text-editions-of-journals-since-2014-/2015-god/2016-03_VEB.pdf (In Russ.)

6. Khominich I.P. [Russian insurance market on the conditions of reforms of the financial regulator]. Bankovskie uslugi = Banking Services, 2013, no. 7, pp. 32-37.

URL: http://finvector.ru/wp-content/uploads/2017/10/bu-07-2013.pdf (In Russ.)

7. Shor I.M. [Process approach to financial resources formation of insurance companies]. Vestnik Volgogradskogo gosudarstvennogo universiteta. Seriya 3: Ekonomika. Ekologiya = Science Journal of VolSU. Global Economic System, 2013, no. 1, pp. 187-195.

URL: https://volsu.ru/upload/medialibrary/4e8/3_Шop\%20И.M..pdf (In Russ.)

8. Knyazeva E.G. [Theoretical and methodological basis of categoric insurance]. Fundamental'nye issledovaniya = Fundamental Research, 2007, no. 12, pp. 315-316.

URL: https://fundamental-research.ru/ru/article/view?id=4206 (In Russ.)

Please cite this article as: Magomadova M.M. Analysis of Business Models for the Takaful Fund Management. Digest Finance, 2018, vol. 23, iss. 3, pp. 308-318. 
9. Fukina S.P. [Features of the organization of Islamic insurance and prospects of its introduction into the insurance market of Russia]. Vestnik Astrakhanskogo gosudarstvennogo tekhnicheskogo universiteta. Seriya: Ekonomika = Vestnik of Astrakhan State Technical University. Series: Economics, 2014, no. 1, pp. 108-116. (In Russ.)

10. Sholoiko A.S. [Features of Takaful insurance]. Ekonomika i banki = Economy and Banks, 2016, no. 1, pp. 33-39. URL: http://ojs.polessu.by/EB/article/view/703/700 (In Russ.)

11. Umarov Kh.S. [On the Islamic insurance "takaful"]. Strakhovoe delo, 2014, no. 4, pp. 47-53. (In Russ.)

12. Magomadova M.M., Isaeva E.A. [Evaluation of the market prospects for Islamic insurance (takaful) in Russia and in the North Caucasus regions (the Chechen republic example)]. Vestnik Tverskogo gosudarstvennogo universiteta. Seriya Ekonomika I upravlenie = Herald of TVSU. Series Economics and Management, 2015, no. 3, pp. 225-233. URL: https://core.ac.uk/download/pdf/74272775.pdf (In Russ.)

13. Magomadova M.M. Implementation of Takaful Insurance System in the Russian Federation and Its Future. Middle-East Journal of Scientific Research, 2013, vol. 16, iss. 9, pp. 1178-1182. URL: https://doi.org/10.5829/idosi.mejsr.2013.16.09.11977

14. Logvinova I.L. [Genesis of mutual insurance]. Ekonomicheskie nauki = Economic Sciences, 2010, no. 65, pp. 69-78. (In Russ.)

\section{Conflict-of-interest notification}

I, the author of this article, bindingly and explicitly declare of the partial and total lack of actual or potential conflict of interest with any other third party whatsoever, which may arise as a result of the publication of this article. This statement relates to the study, data collection and interpretation, writing and preparation of the article, and the decision to submit the manuscript for publication. 